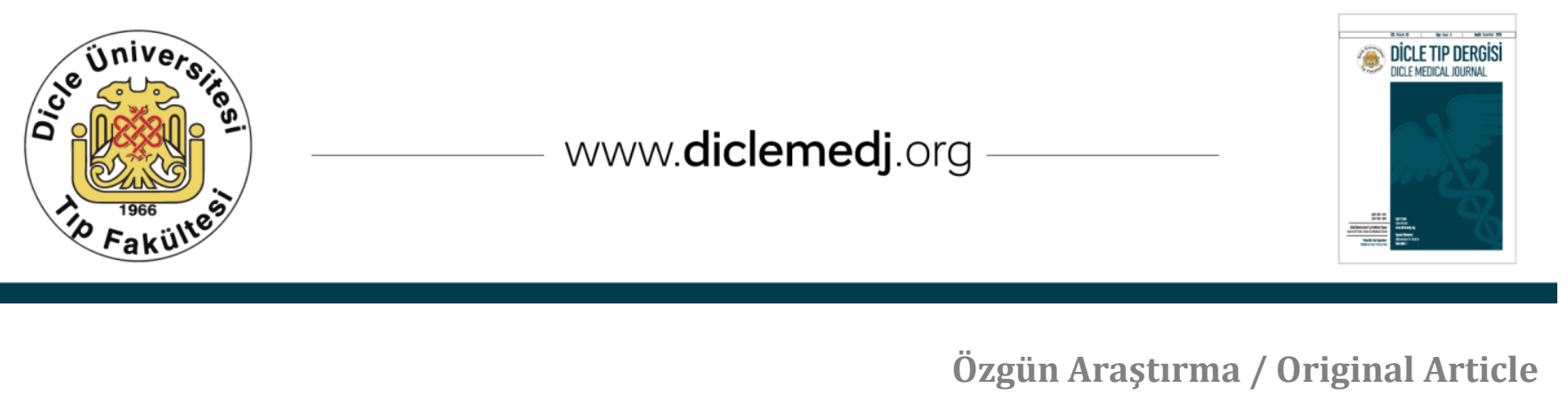

\title{
Pektus Bar'lı Olguların Serum ve İdrar Örneklerinde Eser Elementlerin Değerlendirilmesi
}

\author{
Murat Akkuş ${ }^{1}$ \\ 1 İstanbul Mehmet Akif Ersoy Göğüs Kalp ve Damar Cerrahisi Eğitim ve Araştırma Hastanesi, Göğüs Cerrahisi, İstanbul, Türkiye \\ ORCID: 0000-0002-3762-6328
}

Geliş:10.05.2019; Revizyon: 22.07.2019; Kabul Tarihi: 23.07.2019

Öz

Amaç: Göğüs deformitelerinin metal alaşımlı barlar vasıtasıyla rekonstrüksiyon yönteminin kullanılması, metal barlara bağlı eser elementlerin vücuda yayılmasına da sebep olabilmektedir. Bu çalışma, pektus bar kullanılan sinırlı sayıda olguda serum ve idrarlarında bar alaşımı olan Demir(Fe), Nikel(Ni) ve Krom(Cr) seviyeleri analiz edilmiş ve literatürle karşılaştırılarak bir ön çalışma olarak sunulması amaçlanmıştır.

Yöntemler: Daha önce bar takılmış11 Erkek (E) ve 3 Kadın (K) toplam 14 olgunun ortalama bar kalıs süresi 39,70 (760) ay sonunda alınan serum ve idrarlarında $\mathrm{Fe}$, $\mathrm{Ni}$ ve $\mathrm{Cr}$ seviyeleri çözündürülerek indüktif plazma kütle spektrofotometresi (ICP-MS) cihazı ile değerlendirildi. Sonuçlar literatür ile karşılaştırıldı.

Bulgular: Serum Fe ve Ni seviyeleri normal değerler arasında saptanırken serum Cr seviyesi normal değerlerden yüksek saptanmıştır. İdrar da ise $\mathrm{Fe}$ ve $\mathrm{Cr}$ atılımı normalin çok üstünde bulunurken Ni idrarda normal seviyede saptanmıştır.

Sonuç: İdrar Fe atılımı arttırılarak serum Fe seviyesinin normal tutulması sağlanabilmiş, ancak idrar Cr atılımı artmasına rağmen serum $\mathrm{Cr}$ seviyesi yüksek saptanmıştır. Bu da yüksek $\mathrm{Cr}$ serum seviyesinin vücutta birikici etki oluşturabileceği şeklinde yorumlanmıştır.

Anahtar kelimeler: Metal salınımı; İyon salınımı; Eser element analizi; Çelik bar; Metal toksisitesi.

DOI: $10.5798 /$ dicletip.620523

Yazışma Adresi / Correspondence: Murat Akkuş, İstanbul Mehmet Akif Ersoy Göğüs Kalp ve Damar Cerrahisi Eğitim ve Araştırma Hastanesi, Göğüs Cerrahisi, İstanbul, Türkiye e-mail: akkusmdr@gmail.com.tr 


\title{
Evaluation of Trace Elements in Serum and Urine Samples of Patients with Pectus Bar
}

\begin{abstract}
Objective: The use of metal alloy bars in the reconstruction of thoracic deformities causes spread of trace element into the body. The aim of our study was to analyses and compare the levels of common alloy bar elements such as Iron $(\mathrm{Fe})$, Nickel (Ni) and Chromium ( $\mathrm{Cr}$ ) in the serum and urine samples in a limited number of cases using pectus bars with the available literature reviews.

Method: The levels of $\mathrm{Fe}, \mathrm{Ni}$, and $\mathrm{Cr}$ in the serum and urine samples of 14 patients (11 males, 3 females) with an average pectus bar treatment duration of 39,70 (7-60) months were determined (just before removal of the bar) using Inductive Plasma Mass Spectrophotometry (ICP-MS).

Results: The serum Fe and $\mathrm{Ni}$ levels were found to be within the normal range while Cr levels were found to be higher than normal. On the other hand, the levels of $\mathrm{Fe}$ and $\mathrm{Cr}$ excretion were found to be higher than normal in the urine while Ni level was found to be normal.

Conclusion: The serum Fe level was kept normal as a result of the increase in the urine Fe excretion whereby serum $\mathrm{Cr}$ level was found to be higher than normal despite the increase in excretion of $\mathrm{Cr}$ in the urine. Therefore, the higher serum $\mathrm{Cr}$ level may have resulted as accumulative effect of $\mathrm{Cr}$ in the body.
\end{abstract}

Keywords: Metallic release; Ionic release; Trace element analysis; Stainless steel; Metal toxicity.

\section{GİRIŞ}

Çelik bar (Demir-FE, Krom-Cr, Nikel-Ni) ve tıbbi kullanılan saf Titanyum (Ti) metal barlar gögüs deformitelerinde yaygın olarak kullanılmaktadır. Vücut içinde en sık kullanılan implantlardan olması, mekanik dayanıklılığı ve operasyonda hastaya göre kolaylıkla şekillendirilebilmesi nedeniyle en sık çelik barlar göğüs deformitelerinde kullanılmaktadır. Bununla beraber yüzey korozyonu oluşması ve yüksek oranda lokal ve sistemik metal iyonları salınım dezavantajları da yapılan çalışmalarda tespit edilmiştir ${ }^{1}$.

Metal implantlardan metal iyonlarının salınımı implantların biyouyumluluğunu ve güvenliğini tartışmalı hale getirmektedir. Eğer yüksek miktarda metal iyonları salınımı varsa insan sağlığı için büyük zararlara yol açabilmektedir. Serbestleșen metal iyonları yumuşak dokuda reaksiyon, metobolizmaya etkileri, organlarda birikim, allerji ve kanser gibi çok sayıda klinik probleme yol açabilir².

Bu çalışma, pektus bar kullanılan sınırlı sayıda olguda kan ve idrarlarında $\mathrm{Fe}$, $\mathrm{Ni}$ ve $\mathrm{Cr}$ seviyeleri analiz edilmiş ve literatürle karşılaștırılarak bir ön çalışma olarak sunulması amaçlanmıştır.

\section{YÖNTEMLER}

Daha önce bar uygulanmış 11 Pectus Excavatum, 3 Pectus Carinatum toplam 14 olgu çalışmaya dahil edildi. Olguların 11 Erkek, 3 Kadın olup yaşları ortalama 16,64 +/-4,44 (824) yıl arasında değişmekte idi. Olgularda bar kalış süreleri ortalama 39,70 (7-60) ay olarak izlendi. Araştırma kapsamına dahil edilen hastalardan operasyon öncesi bar çıkarılmadan intravenöz olarak $10 \mathrm{ml}$ kan örneği ve idrar alındı. Kan örnekleri $\mathrm{Fe}, \mathrm{Cr}$ ve Ni seviyelerinin analizi için EDTA (Etilen Diamin Tetraasetik Asit) içeren tüplere depolandı.

Analizlerde kullanılan tüm kimyasal maddeler analitik saflıkta olup, çözeltilerin hazırlanmasında ultra saf su kullanıldı. ICP-MS cihazının kalibrasyonu, Merck firmasının 1000 $\mathrm{mg} / \mathrm{L}$ 'lik $\mathrm{Fe}, \mathrm{Cr}$ ve $\mathrm{Ni}$ stok çözeltileri kullanılarak analizler için uygun konsantrasyonlarda çözeltiler hazırlandı.

Örnekler Milestone Ethos 900 marka mikrodalga cihazında çözünürleştirildi. Örneklerin element ölçümleri Perkin Elmer Sciex Elan DRC-E model indüktif eşleşmiş 
plazma kütle spektrofotometresi (ICP-MS) ile yapildl.

Mikrodalga Çözündürme metodu:

4 Dakika 250 Watt

5 Dakika 0 Watt

4 Dakika 300 Watt

5 Dakika 400 Watt

6 Dakika 500 Watt

\section{Kan örneklerinin Fe, Cr ve Ni analizi için hazırlanmasi:}

$\mathrm{Fe}, \mathrm{Cr}$ ve $\mathrm{Ni}$ düzeylerinin belirlenmesi için alınan kan örnekleri -80 C'de saklandı. Kan örnekleri mikrodalga cihazında çözündürüldü. Cihazın her bir numune kabının içerisine 0,3$0,5 \mathrm{~g}$ serum ve idrar örneği konulduktan sonra üzerine $6 \mathrm{ml} \% 65^{\prime}$ lik $\mathrm{HNO}_{3}$ ve $3 \mathrm{ml} \% 30$ 'luk $\mathrm{H}_{2} \mathrm{O}_{2}$ ilave edildi. Ağzı kapatılan kaplar firına yerleştirildikten sonra cihazda çözündürme işlemleri gerçekleştirildi ve çözündürme süresi sonunda kapların oda sıcaklığına kadar soğuması beklenildi. Daha sonra kaplar çıkarılarak kap içeriği 10 ml'lik balon jojeye alınmış, bidistile su ile hacmi 10 ml'ye tamamlandi.

Etik Kurul: Tüm olgulardan çalışmaya katılmaları konusunda bilgilendirilmiş onam formu alındı. Lokal Etik Kurul onay kararı alınmıştır (03.10.2013/11).

Istatistik: Bulgular standart sapma, ortalama, minimum ve maksimum değerler olarak tanımlayıcı istatistik ile değerlendirildi. Sonuçlar toplanması ve değerlendirilmesi Excel software (Microsoft Corp., Seattle, WA,USA) ile yapıldı.

\section{BULGULAR}

Hastaların serum ve idrarda bulunan $\mathrm{Fe}, \mathrm{Cr}$ ve $\mathrm{Ni}$ değerleri ve literatürdeki kontrol grubu tablo da izlenmektedir ${ }^{3}$. Tablodaki verilere bakıldığında serum eser element $\mathrm{Fe}$ ve $\mathrm{Ni}$ seviyeleri normal sinırlarda yer alırken, serum Cr seviyesi normal sınırların oldukça üstünde çıkmıştır. Yine tabloda idrarlarda element seviyelerinden Ni miktarı normal sinırlarında yer alırken, $\mathrm{Fe}$ ve $\mathrm{Cr}$ element atılımı oldukça artmıştır. İdrarda ve serumda $\mathrm{Cr}$ seviyesi yüksek bulunmuștur.

Tablo: Serum ve idrarda eser element seviyeleri

\begin{tabular}{|ccccc|}
\hline \multirow{2}{*}{ Element } & Hastaserum $(\boldsymbol{\mu g} / \mathbf{l})$ & $\begin{array}{c}\text { Kontrol serum } \\
(\boldsymbol{\mu g} / \mathbf{l})\end{array}$ & Hastaİdrar $(\boldsymbol{\mu g} / \mathbf{l})$ & $\begin{array}{c}\text { Kontrol idrar } \\
(\boldsymbol{\mu g} / \mathbf{l})\end{array}$ \\
\hline $\mathbf{F e}$ & $4724,72+/-1048,04(3583-8779)$ & $120-4800$ & $4253,30+/-358,90(3724-6042)$ & $100-400$ \\
$\mathbf{C r}$ & $412,83+/-81,34(331-682)$ & $0,12-61$ & $108,40+/-42,40(24-158)$ & $0,2-7,2$ \\
$\mathbf{N i}$ & $37,46+/-30,97(17-67)$ & $0,15-710$ & $45,90+/-14,59(18-93)$ & $0,3-75$ \\
\hline
\end{tabular}

\section{TARTIŞMA}

Çalışmaya alınan olguların bar çıkarılma operasyonundan önce alınan örneklerde serum Cr seviyesi normal sınırların oldukça üstünde çıkmıştır. Pektus barlı olgularda bu kadar yükselme barlardan sistemik dolaşıma metal iyonlarının geçmesiyle açıklanabilir. Serum Fe seviyesi normal olan pektus barlı olgularda idrar $\mathrm{Fe}$ seviyesinin oldukça artması, yine barlardan dolaşıma metal iyonlarının geçtiği ancak idrar atılımının oldukça artarak serum seviyesinin normal sinırlarda tutabildiğini göstermektedir. İdrarda $\mathrm{Cr}$ seviyesi yüksek olmasına rağmen serum $\mathrm{Cr}$ seviyesinin yüksekliği, pektus barlı olgularda $\mathrm{Cr}$ iyonunun yüksek oranda sistemik dolaşıma geçtiği, artmıș $\mathrm{Cr}$ atılımının serum seviyesini düșürmeye yetmediği ve serumda $\mathrm{Cr}$ birikimine yol açtığını düşündürmektedir. 
Metalik protezlerle yapılan çalışmalarda plazma ve idrarda, protezle ilişkili elementlerde artışlar daha önceden saptanmıştır ${ }^{4}$ Bu iyonların öncelikle dokuyla temas eden bölgede artış gösterdiği ve makrofajlar tarafından fagosite edilerek veya çözülebilir iyon partikülleri olarak proteinlere bağlanıp metaloprotein olarak vasküler yolla dolaşıma katıldığı ve organlarda birikim yaptığı belirtilmiştir5,6. Rubio ve ark. çalışmalarında Kobalt krom (CoCr) , Titanyum (Ti) ve MA950 kaplı alfa Aliminyum (Al) alaşımlar kullanmış, 12 ay sonunda denekler sakrifiye edilerek organlardaki iyonlar incelenmiştir. Dalakta en yüksek oranda $\mathrm{Cr}$ ve $\mathrm{Ti}$ saptanmışken idrar tarafından atılmasına rağmen böbrekte ağırlıklı olarak Co saptanmıştır. Al organlarda saptanmamış olup bunun yüzeyin kaplı olmasına bağlı korozyona uğramayıp degrade olmamasına bağlanmıștır. Uzun dönem sonunda organlarda $\mathrm{Cr}$ ve $\mathrm{Ti}$ biriktiği saptanmıştır(2).

Metal iyonlarının konulan protezin korozyonundan başladığına dair çok sayıda yayın bulunmaktadır ${ }^{7,8}$. Metalik protezlerden çevre dokuya veya sistemik dolaşımla organlara iyon birikimi sonucu toksik olaylar gelişimi ile ilgili yayınlar tartışmalıdır. Metallerden iyon salınımına bağlı toksik bulgular birçok çalışmada tarif edilmiştir ${ }^{9,10}$. Bununla beraber uzun yillar metal protezli olup kan tablosunda $\mathrm{Cr}$ seviyesinin artmasina rağmen herhangi bir toksik veya alerjik bulgu saptanmadığı da bildirilmiştir ${ }^{4}$. Çalışmalar karışım alaşımlarda en sık birikici elementin $\mathrm{Cr}$ olduğunu desteklemektedir ${ }^{11}$. Bizim çalışmamızda da serumda en çok birikici element olarak $\mathrm{Cr}$ saptand. Bununla beraber en uzun 60 ay olarak pektus barı kalmasina rağmen olgularda toksik bulguya rastlanmadı.

Dokuya veya kana geçen metal iyonlarının yol açtığı reaksiyonların enfeksiyon değil, allerjik reaksiyona yol açtığı ilk defa 2007 yllında yaptıkları yayınla Rushing ve ark. tarafından bildirilmiştir. Retrospektif olarak yapılan çalışmada metal alerjisi \%2,2 oranında saptanmış olup sıklıkla enfeksiyon bulgusu olmadan ateş, kızarıklık, effüzyon ve granülasyon formasyonu olarak tariflenmiştir ${ }^{12}$. Aynı grup tarafından genişletilmiş ikinci retrospektif yayında metal allerjisi \%6,4 bulunmuştur. Metal allerjisi oranının artmış olmasına gerekçe olarak da aslında allerjik reaksiyon olan klinik bulguların önceden enfeksiyon olarak değerlendirilmesinden belirtmişlerdir ${ }^{13}$.

kaynaklandığını

Fortmannve ark. tarafından yapılan çalışmada Nuss operasyonuna alınan 20 olguda metal bar yerleştirilmeden önce doku, kan ve idrarda barda bulunan ağırlıklı elementler olan $\mathrm{Cr}, \mathrm{Ni}$ ve Co bakılmıştır.Barlar 3 yıl kaldıktan sonra tekrar alınan ayn örneklerde serum Co seviyelerinde değişiklik görülmemiş, idrarda $\mathrm{Cr}$ ve kanda $\mathrm{Ni}$ seviyelerinde kendi kontrol kanlarına oranla anlamlı artış saptanmıştır. Yine dokuda hayli yüksek oranda $\mathrm{Ni}$ ve $\mathrm{Cr}$ seviyeleri tespit etmişler, Co'ın dokuda daha düşük oranda arttığını izlemiş̧lerdir. Kanda Ni seviyesi artmasına rağmen Niallerjisi bulgusuna rastlanmadığını ifade etmişlerdir ${ }^{14}$. Yine Cundy ve ark. Nuss operasyonu ile bar konulan 11 çocuk olguda $\mathrm{Cr}$, Ni ve molibden'in serum seviyelerini değerlendirmişlerdir. $\mathrm{Ni}$ seviyesini 3,3 kat, $\mathrm{Cr}$ seviyesini 2,3 kat kontrol grubunun serum seviyesinden yüksek bulmuşlardır. Herhangi bir toksik etki izlememişlerdir. Bar çıkarılması sonrası serum $\mathrm{Cr}$ ve $\mathrm{Ni}$ seviyelerinin zaman içerisinde düştüğünü saptamışlardır ${ }^{15}$.

Metal alaşımlar diz, spinal cerrahi gibi diğer operasyonlarda da kullanılmış ve göğüs deformitesinde kullanılan metal alaşımlarla benzer sonuçlar yayınlanmıştır. Kim ve ark. tarafindan, posteriyor spinal artrodezisde kullanılan metal alaşımların operasyondan sonra kaldığı süre ile serum $\mathrm{Cr}$ ve $\mathrm{Ni}$ oranlarının yükselmesi arasında anlamlı ilişki olduğu ifade etmişlerdir. Metal alaşımların yerleştirilme operasyonu sonrası hızla serum 
Ni ve Cr seviyeleri artan olgularin 2 yıl sonunda en yüksek seviyelere çıktığı, sonraki iki yılda düştüğü ve 4 yll üstünde ise normal serum seviyelerine yaklaştığını saptamışlardır. Bunu metal alaşımların etrafında oluşan pseudoartroz gelişimi ve bunun vasıtasıyla degrade olan alaşımın seruma geçmesiyle açlklanabileceğini belirtmişler, kendi vakalarında pseudoartroz gelişmemesi nedeniyle iyon seviyelerinin zamanla düşme gözlendiğini iddia etmişlerdir ${ }^{16}$. Kırık tamirlerinde transosseoz $\mathrm{Ni}$ alaşımlı metal tel ve metal implant kullanımları ile yapılan yayın derlemesi sonucunda $\mathrm{Ni}$ alaşım kullanımının allerjik ve toksik etkiler nedeniyle oluşabilecek komplikasyonlardan dolayı tercih edilmeyebileceği belirtilmiştir ${ }^{17,18}$.

\section{Limitasyon}

Çalışmanın örnek sayısının düşük olması sınırlayıcıdır. Çalışmaya alınan olguların kan ve idrar eser element seviyelerinin literatürle karşılaştırılması çalışmayı kısıtlamaktadır. Daha geniş serilerde karşılaştırmalı çalışmalar için ön çalışma olarak sunumu yapılmıştır.

\section{SONUÇ}

Pektus barlı olgularda bar kalış süresi sonunda alınan serum ve idrar örneklerinde $\mathrm{Fe}, \mathrm{Cr}$ ve $\mathrm{Ni}$ seviyelerine bakılmış, özellikle serumda $\mathrm{Cr}$, idrarda $\mathrm{Fe}$ ve $\mathrm{Cr}$ seviyesinde artış saptanmıştır.İdrar Fe atılımının arttırılarak serum Fe seviyesinin normal tutulması sağlanabilmiş, ancak idrar $\mathrm{Cr}$ atılımı artmasına rağmen serum Cr seviyesi yüksek bulunmuştur.

Çıkar Çatışması Beyanı: Bu çalışmada çıkar çatışması yoktur.

Finansal Destek: Bu çalışma herhangi bir fon tarafından desteklenmemiştir.

Declaration of ConflictingInterests:There is noconflict of interest in thisstudy.

Financial Disclosure: No

financialsupportwasreceived.

\section{KAYNAKLAR}

1. Kajzer A, Kajzer W, Dzielicki J. et all. The study of physicochemical properties of stabilizing plates removed from the body after treatment of pectus excavatum. Acta of Bioengineering and Biomechanics. 2015; 17: 35-42.

2. Alonso Rubio JCG, Alonso MC, Clemente MA, et all. Determination of metallic traces in kidneys, livers, lungs and spleens of rats with metallic implants after a long implantation time. Journal of Materials Science:Material in Medicine; Jan 2008, Vol.19 Issue 1, 369-75.

3. Avino P, Capannesi G, Manigrasso M, et all. Element assessment in whole blood, serum and urine of three Italian healty subpopulatıons by INAA. Microchemical Journal, 2011, Nov 1; 99: 548-55.

4. Pazzaglia UE, Minoia C, Gualtieri I, et all. Metal ions in body fluids after arthroplasty. Acta Orthop. Scand. 1986 Oct; 57: 415-8.

5. Chassot E, Ouadedesse H, Barbotteau Y, et all. Tentavive for trace elements evalation by pixe method versus depth in soft tissues near metallic implants. Journal of Trace and Microprobe Techniques, 2002, Vol.20: 571-80.

6. Graham JA, Gardner DE, Waters MD, et all. Effect of trace metals on phagocytosis by alveolar macrophages. Infection and immunity. 1975 Jun 1; 11: 1278-83.

7. Lopez GD. Biodeterioration and corrosion of metallic implants and prostheses. Medicina. 1993; 53: 260-74.

8. Krischak GD, Gebhard F, Mohr W, et all. Difference in metallic wear distribution released from commercially pure titanium compared with stainless steel plates. Arch Orthop Trauma Surg. 2004, Mar 1; 124: 10413.

9. Zhou Z, Liu X, Liu Q, et all. Evaluation of the potential cytotoxicity of metals associated 
with implanted biomaterials. Preparative Biochemistry \& Biotechnology, 2008,Dec 23; 39: 81-91.

10. Fraga G. Cesar. Relevance, essentiality and toxicity of trace elements in human health. Moleculer Aspect of Medicine. 2005, Aug 1; 26; 235-44.

11. Michel R, Hofmann J, Löer F, et all. Trace element burdening of human tissues due to the corrosion of hip - joint prostheses made of cobalt-chromium alloys. Archives of Orthopaedic and Trauma Surgery. 1984, June 1; 103: 85-95.

12. Rushing GD, Goretsky MJ, Gustin T, et all. When it is not an infection: metal allergy after the Nuss procedure for repair of pectus excavatum. Journal of pediatric surgery. 2007, Jan 1; 42: 93-7.

13. Shah B, Cohee A, Deyerle A, et all. High rates of metal allergy amongst Nuss procedure patients dictate broader pre-operative testing. Journal of pediatric surgery. 2014 Mar 1; 49: 451-4.
14. Fortmann C, Göen T, Krüger M, et all. Trace metal release after minimally-invasive repair of pectus excavatum. PloS one. 2017 Oct 12; 12: e0186323.

15. Cundy TP, Kirby CP. Serum metal levels after minimally invasive repair of pectus excavatum. Journal of pediatric surgery. 2012 Aug 1; 47: 1506-11.

16. Kim YJ, Kassab F, Berven SH, et all. Serum levels of nickel and chromium after instrumented posterior spinal arthrodesis. Spine. 2005 Apr 15; 30: 923-6.

17. Nwashindi A, Dim EM. Adverse effects of nickel in transosseous wires and surgical implants: literature review. Nigerian journal of medicine: journal of the National Association of Resident Doctors of Nigeria. 2014; 23: 335-43.

18. Falagiani $P$ et al. Systemic nickel allergy syndrome (SNAS): A review. Rev Port Immunoalergologia 2008; 16: 135-47. 